\title{
Smoezen om niet te hoeven leren?
}

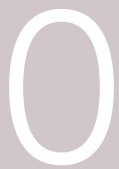

m mijn zoon (18) aan te sporen meer aandacht te besteden aan zijn schoolwerk, googelde ik op mogelijk behulpzame strategieën. Ik kwam op sites terecht met trefwoorden als durf te leren; eindeloos leren; zelf het wiel uitvinden: niet doen; zelf het wiel uitvinden: wel doen; leren voor dummies (excuus) en smoezen om niet te hoeven leren.

En ik zat midden in mijn werk. In het kennisprogramma Vakkundig aan het werk stellen we onderzoeksbudget beschikbaar voor het ontwikkelen van toepasbare kennis om de dienstverlening van gemeenten op het terrein van Werk en Inkomen te verbeteren. Best een uitdaging om goede onderzoeksprojecten te genereren die waarmaken wat de uitvoerders daarvan beloven. Dat wil zeggen de effectiviteit en werkzame elementen van interventies aantonen en de resultaten overdraagbaar maken voor andere gemeenten. Maar de grootste uitdaging in het programma is het toepasbaar maken van de verkregen kennis in het handelen van alledag. Zodat gemeenten, gewapend met wetenschappelijke inzichten, gedeelde professionele kennis én kennis van de cliënten zelf een verbeterslag maken in hun professioneel handelen. Liefst zodanig dat we kunnen spreken over 'evidence based handelen'. Dit gesteund door een 'lerende organisatie' met achter de hand een lerend, landelijk opererend, kennisnetwerk om de kennis verder te ontwikkelen. We vragen nogal wat...

\section{Circus}

Nieuwe werkwijzen aanleren gaat niet zo maar en iedereen leert op zijn eigen wijze. We krijgen vanuit gemeenten signalen dat de roep om professionalisering soms meer verlammend dan stimulerend werkt. Een circus van congressen, trainingen, voorbeeldprojecten en het ontwikkelen van een breed scala aan infographics en werkwijzers is echt niet voldoende.

Even een blik naar mijn zoon achter zijn laptop op de bank. Ik zie filmbeelden voorbij flitsen. Hoe denkt hij zelf eigenlijk over leren? Wat bleef hangen van mijn google-actie is, met dank aan Berthold Gunster ${ }^{1}$, dat het helpt om van een probleem (in dit geval 'geen ruimte of zin om te leren') een feit te maken. En dit feit te accepteren zoals het is. Dit biedt vervolgens de kans om nieuwe mogelijkheden te zoeken in plaats van te blijven vechten tegen een probleem.

Niet vechten tegen windmolens, maar mee bewegen met een gegeven dat eerst een probleem leek. Zo mee waaiend aan de wieken van die molen hoor ik mijn zoon antwoorden dat 'zelf iets actiefs doen' fijner leert dan saai geïnformeerd te worden door een ander, dat hij eigenlijk heel hard onbewust zit te leren (?) en dat hij van de website met filmpjes - waar hij zojuist naar keek - meer geleerd heeft dan uit zijn leerboek. En ineens hoor ik daar tussendoor de klantmanager die ik gisteren sprak opnieuw: 'Ik heb in maanden niet zoveel geleerd als in die ene intervisie-sessie met mijn collega's.' Dit stelt gerust. We hebben in Vakkundig aan het werk onlangs zeven projecten gehonoreerd op het terrein van integraal werken. ${ }^{2}$ In deze projecten gaan gemeentelijke professionals en onderzoekers aan de slag met casuïstiekvoering over de domeingrenzen heen. Zeven groepen zijn enthousiast van start gegaan om samen actief te leren. Voor hen geen smoezen meer. Ik wens hen en ons veel leerervaringen toe!

Femke Reijenga,

Programma-secretaris bij ZonMw

\section{Noten}

1. omdenken.nl

2. zonmw.nl/vakkundigaanhetwerk 